\title{
POTENSI PENGEMBANGAN USAHA BUDIDAYA IKAN PATIN (Pangasius SP) DI DESA TATELU KABUPATEN MINAHASA UTARA
}

\author{
Agus Rumimpunu'; Jardie A. Andaki'; Victoria E.N. Manoppo² \\ 1) Mahasiswa Fakultas Perikanan dan IImu Kelautan Universitas Sam Ratulangi, Manado. \\ 2) Staff Pengajar Fakultas Perikanan dan IImu Kelautan Universitas Sam Ratulangi, Manado. \\ Koresponden email: aguzpunu@yahoo.com
}

\begin{abstract}
The objective of this research was to study the potential business development of Channel catfish farming (Pangasius sp) in Tatelu Village North Minahasa regency. This research was a case study and the data collected was analyzed qualitatively and quantitative. Observation and interview to Tatelu village community were used to gather the primary and secondary data. The results of the research showed that the land, fries, and feed can be used for the potential businnes development of farming channel catfish in Tatelu village of North Minahasa Regency. The problems faced by fish culturist included cost, fish disease, level of community education and market demand. The skill of fish culturist needed to be develop through education , training and socialization about the benefits of fish culture. This was important due to the development of channel catfish farming had positive impact increasing people welfare. This is important because the development of channel catfish farming has a positive impact on improving people's economi

Key words : channel catfish, tatelu village, business development
\end{abstract}

\section{PENDAHULUAN}

Agribisnis yang baik untuk dikembangkan dan memiliki prospek yang cukup baik salah satunya adalah akuakultur. Akuakultur merupakan sektor penghasil makanan dengan perkembangan tercepat dan perkembangan serta peningkatannya terjadi hampir di semua daerah. Populasi global yang meningkat juga meningkatkan permintaan produk akuatik juga meningkat (Subasinghe dan Soto 2009). Bagi negara berkembang dimana menghasilkan $90 \%$ hasil dunia, akuakultur merupakan sumber protein, pekerjaan, pendapatan dan devisa negara (Hishamunda et al. 2009)

Ikan patin merupakan ikan yang semakin di minati di Indonesia dan menjadi salah satu andalan dalam peningkatan produktifitas budidaya. Hal ini dapat dibuktikan dengan peningkatan produksi ikan patin tahun 2015 sebesat 339.069 ton dan meningkat menjadi 437.11 ton pada tahun 2016, produksi patin masih terus meningkat dimana sasaran produksi patin nasional pada tahun 2019 yaitu menjadi 1.149 .400 ton (KKP 2016). Peningkatan produksi ikan dapat dicapai melalui proses akuakultur karena peningkatan produksi melalui penangkapan dapat mengganggu kelestarian sumberdaya perikanan (Andriyanto et al., 2012)

Budidaya ikan patin siam (Pangasius hypopthalmus) sudah mulai dirintis oleh Sub Balai Penelitian Perikanan Air Tawar pada tahun 1980. Salah satu balai yang juga mengembangkan komoditas ikan patin adalah Balai Perikanan Budidaya Air Tawar Tatelu (BPBAT Tatelu) (Adam 2009).

Desa Tatelu Kecamatan Dimebe merupakan salah satu desa yang telah lama melakukan usaha pemeliharaan ikan nila dan ikan mas namun pembudidaya ikan patin di Tatelu masih kurang dibandingkan dengan lahan yang layak untuk dijadikan tempat budidaya ikan patin.

Penelitian ini dilakukan dengan tujuan mengidentifikasi potensi pengembangan usaha budidaya ikan Patin yang terdapat di Desa Tatelu Kecamatan Dimembe Kabupaten Minahasa Utara dan mendeskripsikan faktor pendukung dan peluang potensi pengembangan usaha budidaya ikan patin di Desa Tatelu. 


\section{METODE}

\section{Tempat dan Waktu Penelitian}

Penelitian ini dilaksanakan di

Desa Tatelu Kecamatan Dimembe Kabupaten Minahasa Utara. Penelitian dilakukan bulan Februari sampai Juni 2017.

\section{Pengumpulan Data}

Data yang digunakan adalah data primer dan data sekunder. Pengumpulan data dilakukan dengan metode (Arikunto, 2002). Metode Purposive sampling dimana data diambil dari pembudidaya ikan Patin yang ada di Desa Tatelu Kabupaten Minahasa. Sesuai dengan tujuan yang ingin dicapai, maka penelitian ini bersifat eksploratif atau mengungkapkan keadaaan sebenarnya dari objek penelitian.

\section{Analisis Data}

Potensi pengembangan usaha budi daya ikan patin yang terdapat di Desa Tatelu Kecamatan Dimembe Kabupaten Minahasa Utara dinalisa berdasarkan analisis deskriptif kuantitatif dan deskripsi kualitatif. Dan faktor pendukung dan peluang terhadap potensi pengembangan usaha budidaya ikan patin di Desa Tatelu memakai analisis deskriptif kualitatif melalui penjabaran dari Analisis SWOT (Rangkuti 2008).

\section{HASIL DAN PEMBAHSAN Keadaan Umum Desa Tatelu}

Desa Tatelu merupakan salah satu desa di wilayah Kecamatan Dimembe, yang terletak di Kabupaten Minahasa Utara. Ketinggian dari dasar laut 450 sampai 600 meter dengan suhu rata-rata 20 sampai dengan 29 derajat celcius. Desa Tatelu adalah salah satu Desa di wilayah Kecamatan Dimembe dengan jumlah jaga 6 jaga dengan luas wilayah 1.217 .98 ha. terdiri dari Perkampungan seluas 32,65 ha, ladang/ kebun seluas 778 ha, sawah 214 ha, kolam seluas 65 ha, hutan seluas 90.05 ha, tambang emas seluas 40,27 ha. Jumlah penduduk desa Tatelu sampai tahun 2016 yaitu 1.712 laki-laki dan 1.651 perempuan dari 938 kepala keluarga.

\section{Keadaan Sosial Masyarakat Desa Tatelu}

Ketersediaan/kesiapan petani ikan atau pembudi daya di Desa Tatelu yang dapat mendukung budidaya ikan Patin. Dari 11 responden, sebanyak 4 berpendidikan SMA $(36.36 \%)$ dan 4 lainnya berpendidikan SMP (36.36\%), sedangkan 3 sisanya ber- pendidikan Sarjana $(27.28 \%)$ namun dari data keseluturan penduduk di Desa Tateli yang berpendidikan tamat SMP sebesar $30.45 \%$ dan tamat SMA $21.47 \%$. Pendidikan masyarakat di desa Tatelu Kecamatan Dimembe Kabupaten Minahasa Utara.

Tabel. Pendidikan Masyarakat di Desa Tatelu Kecamatan Dimembe Kabupaten Minahasa Utara

\begin{tabular}{|c|l|r|}
\hline No. & Menurut Status Pendidikan & Jumlah \\
\hline 1. & Tamat SLTP & 994 \\
\hline 2. & Tamat SLTA & 701 \\
\hline 3. & Tamat Akademi / Diploma & 148 \\
\hline 4. & Tamat Perguruan Tinggi & 98 \\
\hline \multicolumn{2}{|c|}{ J u m I a h } & 3.264 \\
\hline
\end{tabular}

Adanya perbedaan tingkat pendidikan dapat mempengaruhi produktifitas kerja yang berdampak langsung terhadap peningkatan produk akuakultur. Upaya lain selain pendidikan formal dapat dilakukan untuk menambah pengetahuan dari pembudidaya tentang cara memelihara ikan patin.

Kelompok empat kelompok pembudidaya di desa Tatelu dengan komoditas ikan budidaya yang berbeda beda seperti: komoditas nila dikelola oleh kelompok tani Merut Mandiri dan Merut dengan jumlah total kolam sebanyak 16 kolam,dan komuditas ikan mas dikelola oleh kelompok tani Pemerta 
dan Sendangan Indah dengan jumlah total kolam 15 kolam.

Desa Tatelu meiliki potensi pengembangan usaha budidaya ikan Patin. Hal itu berdasarkan Balai Budidaya Air Tawar Tatelu Yang memiliki produksi benih dan induk ikan Patin, Sehingga masyarakat dengan mudah untuk memperoleh benih dan induk ikan Patin. Selain itu dari sisi lahan dimana para petani pembudidaya dapat mengembangkan unit usaha budidayanya, mereka pun juga dapat membantu dalam program pengembangan usaha dari budidaya ikan Patin.

\section{Faktor yang Mempengaruhi}

\section{Perkembangan Usaha Budidaya Patin} Sumber daya air

Sumber daya air merupakan kebutuhan utama untuk usaha budidaya ikan air tawar. Air yang melimpah di Desa Tatelu Kecamatan Dimembe Kabupaten Minahasa Utara memberikan peluang kepada masyarakat untuk mengembangkan usaha budidaya air tawar. Irigasi, air sungai dan juga air PAM merupakan modal besar guna memproduksi ikan air tawar melalui kegiatan budidaya.

\section{Sumberdaya Lahan}

Di Desa Tatelu memiliki lahan yang bisa dioptimalkan untuk kegiatan budidaya yaitu dari lahan pembudidaya langsung maupun dari pihak Balai Benih Air Tawar Tatelu tersebut. Kemudidan lahan dari masyarakat umum semuanya dapat dioptimalkan untuk pengembangan budidaya.

\section{Pakan}

Pakan bisa berupa pellet dan dapat diperoleh dari Balai Budidaya Air Tawar Tatelu yang memiliki produksi sendiri dengan harga 11000/kg.
Pasar

Ikan Patin dipasarkan berdasarkan umur ikan Patin seperti untuk pemasokan benih, kebutuhan konsumsi dan permintaan indukan.

\section{Penyakit}

Dalam bisnis pasti ada kendalanya, begitu juga dengan usaha budidaya ikan Patin ini. Kendala yang biasa dialami dalam bisnis ini adalah penyakit akibat infeksi bakteri, jamur atau vitus dan kematian akibat penurunan kualitas air.

Analisis SWOT merupakan perencanaan strategis klasik yang terdiri dari analisis strength (kekuatan), weakness (kelemahan), opportuinity (peluang) dan threat (ancaman). Persentase analisis SWOP menurut jumlah responden.

Tabel. Persentase Analisis SWOT Menurut Jumlah Responden

\begin{tabular}{|c|c|c|c|}
\hline \multicolumn{4}{|c|}{ Kekuatan (Strenght) } \\
\hline No. & Uraian *) & $\begin{array}{c}\text { Jml } \\
\text { Responden } \\
\text { (orang) }\end{array}$ & Persentase( $\%)$ \\
\hline 1. & S1 & 1 & 9,09 \\
\hline 2. & S1, S2, S3 & 4 & 36,36 \\
\hline 3. & S3 & 2 & 18,18 \\
\hline 4. & S3, S4 & 3 & 27,27 \\
\hline 5. & S4 & 1 & 9,09 \\
\hline Toté & & 11 & 100,00 \\
\hline \multicolumn{4}{|c|}{ Kelemahan (Weakness) } \\
\hline 1 & W1 & 2 & 18.18 \\
\hline 2 & W1, W3 & 4 & 36,36 \\
\hline 3. & W2 & 2 & 18,18 \\
\hline 4. & W2,W3 & 3 & 27,27 \\
\hline Toté & & 11 & 100,00 \\
\hline \multicolumn{4}{|c|}{ Peluang (Opportunity) } \\
\hline 1 & 01,03 & 5 & 45,45 \\
\hline 2 & $01,02,03$ & 3 & 27,27 \\
\hline 3. & $\mathrm{O} 2$ & 2 & 18,18 \\
\hline 4. & 02,03 & 1 & 9,09 \\
\hline Toté & & 11 & 100,00 \\
\hline \multicolumn{4}{|c|}{ Ancaman (Threats) } \\
\hline 1 & T1 & 8 & 72,72 \\
\hline 2 & T1, T2 & 3 & 27,28 \\
\hline \multicolumn{2}{|c|}{ Total } & 11 & 100,00 \\
\hline
\end{tabular}

S1 : benih mudah didapatkan

S2 : sistem imunnya kuat 
S3 : tersedia lahan yang luas

S4 : memiliki banyak minat dari penjual dan hanya memerlukan biaya yang rendah

W1: kurangnya minat konsumen

W2 : belum terlaksananya pemasaran ikan patin

W3 : kurangnya sosialisasi dari pemerintah terhadap ikan patin

01 : dalam masa pemeliharaannya cepat

$\mathrm{O} 2$ : belum ada pembudidaya ikan patin dalam skala besar

O3: memiliki harga yang cukup bersaing yang dapat diekspor sampai luar negeri

$\mathrm{T} 1$ : dalam pemasaran kurang minat dari konsumen

T2 : belum tersedia perusahaan yang membutuhkan ikan patin

Dari data di atas dapat dilihat bahwa benih ikan mudah didapat, sistem imunnya yang kuat dan memiliki banyak minat dari penjual dan hanya memerlukan biaya rendah dengan persentasi kekuatannya $36.36 \%$ dari 11 responden. Peluang akan masa pemeliharaan rendah, memiliki harga cukup bersaing sebesar $45 \%$, namun ancaman tertitinggi yang mana dalam pemasaran kurang minat dari konsumen juga diperoleh $72.72 \%$.

Pengelompokan

alternatif dilakukan dalam strategi pengembangan usaha budidaya ikan patin desa Tatelu.

\begin{tabular}{|c|c|c|}
\hline & Strengths & Weaknesses \\
\hline \multirow{4}{*}{ 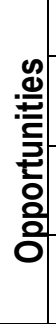 } & $\underline{S / 0}$ & W/0 \\
\hline & $\begin{array}{l}\text { 1) Mengajak masyarakat untuk membuka } \\
\text { usaha budidaya patin }\end{array}$ & $\begin{array}{l}\text { 1) Menyelenggarakan promosi Tentang potensi } \\
\text { kegunaan ikan Patin }\end{array}$ \\
\hline & $\begin{array}{l}\text { 2) Usaha yang sudah ada dapat } \\
\text { dikembangkan }\end{array}$ & $\begin{array}{l}\text { 2) Mengadakan sosialisasi tentang manfaat budidaya } \\
\text { ikan Patin }\end{array}$ \\
\hline & 3) Pembentukan kelompok pembudidaya & $\begin{array}{l}\text { 3) Penyuluhan terhadap masyarakat tatelu khususnya } \\
\text { pembudidaya terkait pemasaran }\end{array}$ \\
\hline \multirow{3}{*}{ 尝| } & $\underline{S / T}$ & W/T \\
\hline & $\begin{array}{l}\text { 1) Dalam pembentukan usaha perlu ada } \\
\text { TPD (tenaga pendamping desa) untuk } \\
\text { membuka usaha budidaya Patin }\end{array}$ & $\begin{array}{l}\text { 1) Perlu ada pelatihan tentang cara Budidaya dan } \\
\text { pemasaran patin }\end{array}$ \\
\hline & $\begin{array}{l}\text { 2) Perlu adanya PPL (penyuluh perikanan } \\
\text { lapangan) dalam rangka memperoleh } \\
\text { hasil yang efektif }\end{array}$ & $\begin{array}{l}\text { 2) Bekerjasama dengan akademisi dan balai } \\
\text { kesehatan ikan dan lingkungan dalam mengatasi } \\
\text { penyakit produk air tawar terutama patin }\end{array}$ \\
\hline
\end{tabular}

\section{KESIMPULAN}

Tersedianya lahan, benih, pakan dasumberdaya manusia yang dapat digunakan untuk pengembangan usaha budidaya ikan Patin yang potensial di Desa Tatelu Kecamatan Dimembe Kabupaten Minahasa Utara. Ketersediaan lahan dan masih kurangnya pembudidaya ikan Patin merupakan peluang pengembangan usaha budidaya ikan Patin.

\section{DAFTAR PUSTAKA}

Andriyanto S, Tahapari E, Insan I.2012. Pendederan Ikan Patin di Kolam Outdoor untuk Menghasilkan Benih Siap Tebar di Waduk
Malahayu, Brebes, Jawa Tengah. Media Akuakultur Volume 7 Nomor 1 Tahun 2012

Arikunto, S. 2002. Prosedur Penelitian Suatu Pendekatan Praktik. Rineka Cipta: Jakarta.

[KKP] Kementerian Kelautan dan Perikanan. 2016. Laporan Kinerja (LKJ) Direktorat Jendral Perikanan Budidaya tahun 2016. Jakarta (ID) : KKP

Hishamunda N, Ridler NB, Bueno P, Yap WP.2009. Commercial aquaculture in Southeast Asia: Some policy lesson. Food Policy 102-107

Rangkuti, F. 2008. Analisis SWOT Teknik Membedah Kasus Bisnis. Gramedia Pustaka Utama, Jakarta.

Subasinghe R, Soto D. 2009Global aquaculture and its role in sustainable development. Reviews in Aquacultur. 1:1-2. 